\title{
NOTE
}

\section{THE BATTLE OVER SUNRISE ROCK: EXAMINING THE CONSTITUTIONALITY OF GOVERNMENT LAND TRANSFERS TO PRIVATE ENTITIES}

Michael Pest $t^{*}$

\section{INTRODUCTION}

Among the 1.6 million acres of southern California's Mojave National Preserve stands a small cross, erected nearly a century ago as a memorial to veterans who died in World War I. ${ }^{1}$ Located in a remote site in the desert atop an outcropping known as Sunrise Rock, the cross, standing between five and eight feet tall, ${ }^{2}$ may appear to be of little significance to the average passerby. However, this seemingly inconsequential monument may have substantial implications for the federal government's ability to transfer land to private entities. The location of the cross in the federally-owned Preserve has sparked widespread debate over whether it violates the First Amendment's Establishment Clause, which guarantees that "Congress shall make no law respecting an establishment of religion." 3 The Establishment Clause is generally interpreted to guarantee citizens the right to be free from the government's endorsement of a particular religion. ${ }^{4}$ Opponents of the cross

\footnotetext{
* J.D. candidate, University of Pittsburgh School of Law, 2011; B.A. 2006, Northwestern University.

1. Buono v. Kempthorne, 502 F.3d 1069, 1072 (9th Cir. 2007).

2. Id.

3. U.S. CONST. amend. I.

4. See Everson v. Board of Education, 330 U.S. 1, 15 (1947) (holding that neither a state nor the
} 
have sought its removal for more than a decade, arguing that its location on the Preserve constitutes governmental endorsement of Christianity. ${ }^{5}$

The case of Salazar v. Buono, ${ }^{6}$ which was decided by the United States Supreme Court on April 28, 2010, is a culmination of this decade-long legal battle. ${ }^{7}$ The central issue in this case was whether the constitutional violation created by the government's endorsement of a particular religion is meaningfully eradicated by its proposal to transfer ownership of the patch of land on which the cross stands to a private entity. ${ }^{8}$ In this case, the government attempted to remedy the constitutional violation by transferring the land to a local veteran's group. ${ }^{9}$ In a 5-4 decision, the Supreme Court held that the transfer was valid and remanded the case to the Ninth Circuit Court of Appeals, thereby resolving a split between the Seventh and Ninth Circuit Courts of Appeals. ${ }^{10}$

The decisions of the Seventh and Ninth Circuit Courts of Appeals over the years demonstrate the divide between the two Circuits on this issue. The Seventh Circuit, in cases such as Freedom from Religion Foundation, Inc. $v$. City of Marshfield, has repeatedly held that, "absent unusual circumstances, a sale of real property conveying a message endorsing religion is an effective way for a public body to end its inappropriate endorsement of religion." 11 Thus, absent unusual circumstances, a governmental transaction is presumed to be an effective remedy for an Establishment Clause violation. The Ninth Circuit, however, in the Buono line of cases, has viewed such transactions with greater scrutiny and has declined to adopt such a presumption when this type of case arises. ${ }^{12}$ Proponents of the Ninth Circuit's views on this issue cite

\footnotetext{
federal government can pass laws which aid one religion, aid all religions, or prefer one religion over another).

5. See generally Buono v. Norton, 212 F. Supp. 2d 1202 (C.D. Cal. 2002).

6. Salazar v. Buono, 130 S. Ct. 1803 (2010).

7. Israel Drazin, The Divisive Mojave Cross, L.A. Times, Oct. 5, 2009, http://articles.latimes.com/ 2009/oct/05/opinion/oe-drazin5.

8. Id.

9. Id.

10. Salazar v. Buono, 130 S. Ct. 1803 (2010). 2000).

11. Freedom from Religion Foundation, Inc. v. City of Marshfield, WI, 203 F.3d 487, 491 (7th Cir.

12. This issue first arose in the Central District Court of California. Buono v. Norton, 212 F. Supp. 2d 1202, 1207 (C.D. Cal. 2002). The District Court determined that the cross violated the Establishment Clause, and the Ninth Circuit affirmed. Buono v. Norton, 371 F.3d 543 (9th Cir. 2004). Buono then brought another action in District Court alleging that the land transfer itself violated the Establishment Clause, and the Court ruled that the transfer violated a permanent injunction against the display of the cross in the Preserve. Buono v. Norton, 364 F. Supp. 2d 1175 (C.D. Cal. 2005). The Ninth Circuit affirmed this ruling. Buono v. Kempthorne, 502 F.3d 1069 (9th Cir. 2007). One year later, the Ninth Circuit issued the amended
} 
the importance of upholding the Establishment Clause and preventing the government from endorsing a particular position. ${ }^{13}$ Supporters of the Seventh Circuit's holdings, on the other hand, demonstrate concern over the Ninth Circuit's supposed disregard of binding Supreme Court precedent, and also point to the potential implications that a restriction on the government's ability to transfer land that it owns may have for the private land owners engaged in such transactions. ${ }^{14}$ Thus, the particular type of transaction at issue in Salazar v. Buono raises First Amendment as well as private property concerns. In rendering a decision in Salazar v. Buono, therefore, the Court was faced with the task of effectively balancing these two important competing interests.

This comment begins with a discussion of the historical background of and rationale for the Establishment Clause, and continues with an examination of the Supreme Court's interpretations of the Clause from the twentieth through the twenty-first century. Part II of this comment discusses the Seventh Circuit and Ninth Circuit's varying approaches to Establishment Clause cases dealing with the transfer of land from a governmental body to a private entity. Specifically, Part II A. analyzes the Seventh Circuit's rationale in deciding the seminal Freedom from Religion Foundation ${ }^{15}$ and Mercier v. Fraternal Order of Eagles ${ }^{16}$ cases. Part II B. discusses the contrasting rationale of the Ninth Circuit in dealing with these types of cases, particularly by examining the Buono cases, the line of cases leading up to the Salazar v. Buono. Part II C. discusses the Supreme Court's ruling in Salazar v. Buono. In Part III, the comment analyzes the competing interests at stake in the Seventh and Ninth Circuit approaches, their relative importance, and the balance that must be struck by the Court in order to adequately address both concerns.

\section{The Establishment Clause}

The First Amendment of the United States Constitution reads, "Congress shall make no law respecting an establishment of religion." ${ }^{17}$ The development of the Establishment Clause most likely arose out of hostility towards the

opinion. Buono v. Kempthorne, 527 F.3d 758, 759 (9th Cir. 2008).

13. See generally Buono v. Kempthorne, 527 F.3d 758, 759 (9th Cir. 2008).

14. Buono v. Kempthorne, 527 F.3d 758, 764-65 (9th Cir. 2008) (O’Scannlain, J., dissenting) (noting that the VFW to which the land containing the Sunrise Rock Cross was sold would be forced to sacrifice its private property rights due to the government's constitutional violation under the majority's approach).

15. Freedom from Religion Foundation, 203 F.3d at 491.

16. Mercier v. Fraternal Order of Eagles, 395 F.3d 693 (7th Cir. 2005).

17. U.S. CONST. amend. I. 
Church of England in the eighteenth century. ${ }^{18}$ Until 1784, any priest belonging to the Anglican tradition-the official state religion in several colonies - had been ordained in London. ${ }^{19}$ By the time of the American Revolution, Anglican priests were held in high suspicion and the framers were reluctant to establish anything resembling an official Church of England in the United States. ${ }^{20}$ An "establishment of religion" in the historic sense is the creation of an established church, or one that is supported by civil authority. ${ }^{21}$ Thus, the First Amendment has generally been interpreted to prohibit the establishment of a national religion by Congress, as well as the preference of one religion over another.

For the nation's first 150 years, the Supreme Court had very few opportunities to interpret the Establishment Clause because the First Amendment had not yet been applied to the states..$^{22}$ In 1947, however, the Court ruled in Everson v. Board of Education that the Establishment Clause applied to the states as well as to the federal government. ${ }^{23}$ In Everson, the court analyzed the constitutionality of a New Jersey statute that authorized its local school districts to make rules and contracts for the transportation of children to and from schools. ${ }^{24}$ The statute authorized a school board to reimburse parents for money they spent on bus transportation for their children, but part of this money was for the payment of transportation of some children in the community to Catholic parochial schools. ${ }^{25}$ Despite upholding the statute's constitutionality, Justice Black, after providing a detailed list of limitations imposed by the Establishment Clause, concluded that the New Jersey statute should be considered in accordance with these First Amendment limitations.$^{26}$ After this ruling, all government action, whether at the federal,

18. Tom Head, The Establishment Clause: What Does The First Amendment's Establishment Clause Really Mean?, http://civilliberty.about.com/od/religiousliberty/a/establishment.htm.

19. Id.

20. $I d$.

21. William H. Marnell, The First Amendment: Religious Freedom in America from Colonial Days to The School Prayer Controversy, at x-xi (1964).

22. Religious Liberty in Public Life, First AMENDMEnt Center, http://www.firstamendmentcenter .org/rel liberty/establishment/index.aspx.

23. Everson, 330 U.S. at 15.

24. Id. at 3 .

25. $I d$.

26. See id. at $15-16$ :

The "establishment of religion" clause of the First Amendment means at least this: Neither a state nor the Federal Government can set up a church. Neither can pass laws which aid one religion, aid all religions, or prefer one religion over another. Neither can force nor influence a person to go to or to remain away from church against his will or force him to profess a belief or disbelief in any religion. No person can be punished for entertaining or professing religious beliefs or disbeliefs, for 
state or local level, became subject to the restrictions imposed by the Establishment Clause. ${ }^{27}$

In the years following the Everson decision, the Court heard a number of Establishment Clause cases and began to develop its modern interpretation of the clause. In the influential 1971 case Lemon v. Kurtzman, the Court established a three-part test for determining whether a particular governmental action constitutes an Establishment Clause violation. ${ }^{28}$ At issue in this case were two state laws: a Pennsylvania statute known as the Nonpublic Elementary and Secondary Education Act, and a Rhode Island statute known as the Rhode Island Salary Supplement Act. ${ }^{29}$ Both of these statutes sought to supplement the salaries of teachers in non-public schools with the use of state funds.$^{30}$ In analyzing the constitutionality of the statutes, the Court concluded that "the statute must have a secular legislative purpose; second, its principal or primary effect must be one that neither advances nor inhibits religion. ... [and] the statute must not foster 'an excessive government entanglement with religion." "'31 Under the Lemon test, if a statute violates any of these three principles, it must be struck down under the Establishment Clause. ${ }^{32}$ In determining whether the statutes in question fostered an excessive entanglement with religion, the Court examined "the character and purposes of the institutions that are benefited, the nature of the aid that the State provides, and the resulting relationship between the government and the religious authority." ${ }^{\prime 3}$ The Court struck down both statutes and based its holding on a number of factors, including the duty of the Rhode Island schools' teachers to stimulate interest in religious vocations and missionary work; the fact that the Pennsylvania statute provided state financial aid directly to church-related schools; the requirement that both states examine

\footnotetext{
church attendance or non-attendance. No tax in any amount, large or small, can be levied to support any religious activities or institutions, whatever they may be called, or whatever form they may adopt to teach or practice religion. Neither a state nor the Federal Government can, openly or secretly, participate in the affairs of any religious organizations or groups and vice versa.

27. Supra note 22.

28. Lemon v. Kurtzman, 403 U.S. 602, 612-13 (1971).

29. Id. at 602 .

30. Id. (The Pennsylvania statute authorized reimbursement to nonpublic schools for teachers' salaries who taught secular materials in such schools, while the Rhode Island statute provided a fifteen percent salary supplement to teachers in nonpublic schools at which the average per pupil expenditure on secular education was below the average in public schools. In both states, the majority of these funds were spent on Catholic schools.).

31. Id. at $612-13$.

32. Stone v. Graham, 449 U.S. 39, 40-41 (1980).

33. Lemon, 403 U.S. at 615.
} 
schools' records in order to determine how much of the total expenditures were attributable to secular education and how much to religious activity; and the divisive political potential of both state programs. ${ }^{34}$

The Court revisited the issue several years later in Lynch $v$. Donnelly, this time examining whether a Christmas display in a public area which contained a Nativity scene violated the Establishment Clause. ${ }^{35}$ With its ruling in Lynch, the Court modified the approach of the Lemon Court by promulgating the endorsement test. ${ }^{36}$ The Lynch Court narrowed the scope of the Lemon test, holding that the crucial inquiry in determining if an Establishment Clause violation exists is whether a government practice has the effect of communicating a message of government endorsement or disapproval of religion. ${ }^{37}$ Thus, under this analysis, a violation only occurs in cases where the government is affirmatively endorsing religion. ${ }^{38}$ In Lynch, the Court found that while the Nativity scene does have religious significance, the display should be allowed to stand because the celebration of Christmas has long been accepted by the western world and the United States government. ${ }^{39}$

Whether the Lemon test or the endorsement test promulgated by the Lynch Court is applied is an unsettled issue and therefore depends in large part on the individual views of the judges hearing a particular case. ${ }^{40}$ There are three competing views concerning how far the protections of the Establishment Clause should extend. ${ }^{41}$ The first of these views is strict separation, which advocates a complete separation of church and state, and a secular government. ${ }^{42}$ Proponents of the second view of the Establishment Clause's scope argue that the Clause commands that the government should be neutral with regard to religion, neither favoring one religion over another

34. Id. at 616-22.

35. Lynch v. Donnelly, 465 U.S. 668 (1984).

36. Kassandra J. Slaven, Comment, $A$ Cross-Examination of the Establishment Clause and Boise's Table Rock Cross, 45 IDAHo L. REv. 651, 657 (2009).

37. Lynch, 465 U.S. at 692.

38. Slaven, supra note 36 , at 657.

39. Lynch, 465 U.S. at 669 (holding that "it would be ironic if the inclusion of the crèche in the display, as part of a celebration of an event acknowledged in the Western World for 20 centuries, and in this country by the people, the Executive Branch, Congress, and the courts for 2 centuries, would so 'taint' the exhibition as to render it violative of the Establishment Clause. To forbid the use of this one passive symbol while hymns and carols are sung and played in public places including schools, and while Congress and state legislatures open public sessions with prayers, would be an overreaction contrary to our history and our holdings.").

40. Slaven, supra note 36 , at $656-57$.

41. Id. at 658 .

42. Erwin Chemerinsky, Why Church and State Should be Separate, 49 WM. \& MARY L. REV. 2193, 2196 (2008). 
nor favoring secularism over religion or vice versa. ${ }^{43}$ Proponents of the third view, known as the accommodationist perspective, believe that the government violates the Establishment Clause only if it literally establishes a church or coerces religious participation. ${ }^{44}$

In recent years, the Supreme Court has not been explicitly clear on which interpretation of the Establishment Clause it supports. ${ }^{45}$ This ambiguity of the Court's recent Establishment Clause jurisprudence is made apparent by the rulings in two cases decided in 2005, Van Orden v. Perry and McCreary Co. v. ACLU of Kentucky. In Van Orden, a dispute arose over the constitutionality of a six-foot-high monolith inscribed with the Ten Commandments that stood on the grounds of the Texas State Capitol. ${ }^{46}$ In ruling that the monument did not violate the Establishment Clause, the majority rejected the Lemon test, explaining that its "analysis is driven both by the nature of the monument and by our Nation's history." ${ }^{47}$ The majority concluded that, since there have been official acknowledgments by all three branches of government of religion's role in American life, and since the Ten Commandments have undeniable historical meaning in addition to their religious meaning, the display did not violate the Establishment Clause. ${ }^{48}$ The Court distinguished this case from Stone v. Graham, which struck down a Kentucky statute requiring the posting of the Ten Commandments in every classroom. ${ }^{49}$ The rationale behind this distinction was that the Texas monument employs a more passive use of the Ten Commandments than was the case in Stone, where the text of the Ten Commandments confronted elementary school students every day in the classroom. ${ }^{50}$

In contrast, in McCreary Co. v. ACLU of Kentucky, the Supreme Court held that the display of the Ten Commandments in Kentucky courthouses constituted a violation of the Establishment Clause. ${ }^{51}$ The county requested that the Court abandon the secular purpose test of Lemon because the true "purpose" of a statute is unknowable. ${ }^{52}$ Justice Souter, writing for the

\footnotetext{
43. Id. at 2197.

44. Id. at 2197-98.

45. See generally Van Orden v. Perry, 545 U.S. 677 (2005); McCreary Co. v. ACLU of Kentucky, 545 U.S. 844 (2005).

46. Van Orden, 545 U.S. at 681.

47. Id. at 686 .

48. Id. at $688-90$.

49. Stone, 449 U.S. at 39.

50. Van Orden, 545 U.S. at 691.

51. McCreary Co., 545 U.S. at 881.

52. Id. at 859
} 
majority, upheld Lemon's secular purpose test and concluded that no such purpose existed in this case. ${ }^{53}$ Despite the fact that the courthouses modified the display several times in an attempt to bring it within constitutional requirements, the Court held that each of these displays was improper, noting that "[a]n observer would probably suspect the Counties of reaching for any way to keep a religious document on the walls of courthouses constitutionally required to embody religious neutrality." 54

While the varying results reached by the Supreme Court demonstrate the muddled nature of Establishment Clause jurisprudence, disagreement among scholars, over both the requirements imposed by the Establishment Clause and the importance of the doctrine, also helps to illustrate this point. Many scholars advocate a strict separation viewpoint, while emphasizing the continuing importance of the Establishment Clause in our country. ${ }^{55}$ One scholar, emphasizing the continuing importance of the Clause, notes that "given the extraordinary religious diversity of our Nation, the Establishment Clause functions to depoliticize religion; it thereby helps to diffuse a potentially explosive situation. ${ }^{16}$ Professor Erwin Chemerinsky adheres to a similar viewpoint, arguing that strict separation is desirable because "it is a way of ensuring that we can all feel that it is 'our' government, whatever our religion or lack of religion. If government becomes aligned with a particular religion or religions, those of other beliefs are made to feel like outsiders." ${ }^{57}$ This is especially important, Professor Chemerinsky argues, given the fact that today the United States is a far more religiously diverse society than the Framers could have ever imagined. ${ }^{58}$

In contrast, several commentators maintain that the Establishment Clause, while requiring some separation, does not require a complete disconnection between church and state. ${ }^{59}$ Many commentators and religious leaders maintain an even more extreme attitude opposing separation, by downplaying the significance of the Establishment Clause and insisting that the United

53. Id. at 861 (holding that examination of purpose is a staple of statutory interpretation for every American appellate court, and governmental purpose is a key element of a good deal of constitutional doctrine).

54. Id. at 848

55. See Leonard Williams Levy, The Establishment Clause: Religion and the First Amendment, at ix-xvi (1986).

56. Id. at ix

57. Chemerensky, supra note 42 , at 2206 .

58. Id. at 2205 .

59. See, e.g., Michael W. McConnell, Why 'Separation' Is Not the Key to Church-State Relations, Christian Century, Jan. 18, 1989, at 43, http://www.religion-online.org/showarticle.asp?title=804. 
States is a "Christian nation" whose laws and government should reflect that "fact." ${ }^{\prime 60}$ The current issue involving the sale of land by a governmental entity and the Establishment Clause implications that such transactions have are a reflection of this widespread and continuing debate.

\section{The Circuit Split over the Sale of Land as an Effective Remedy for Establishment Clause Violations}

An issue that has arisen recently in Establishment Clause cases is whether the transfer of land from a government agency to a private entity is an efficient remedy for any potential Establishment Clause violations. For instance, at the heart of Salazar v. Buono was a dispute over a cross located in the government-owned Mojave National Preserve. In an attempt to keep the cross at its current location atop Sunrise Rock, Congress passed a law instructing the secretary of the interior to transfer ownership of Sunrise Rock and a surrounding acre to a local chapter of the Veterans of Foreign Wars (VFW), a private entity, in order to avoid any Establishment Clause violation. ${ }^{61}$

Cases involving these types of land transfers have reached the Circuit Courts in several instances, and, prior to the Court's ruling in Salazar $v$. Buono, a split existed between the Seventh and Ninth Circuits regarding their constitutionality. ${ }^{62}$ Recent Seventh Circuit decisions indicate that the transfer of land from the government to a private entity is an effective cure for an establishment clause violation, absent any "unusual circumstances" surrounding the transaction. ${ }^{63}$ Conversely, the Ninth Circuit has viewed such transactions with greater scrutiny than the Seventh Circuit, holding in Buono $v$. Kempthorne that it must "decline to adopt a presumption of the effectiveness of a land sale to end a constitutional violation" as the Seventh Circuit did in Marshfield. ${ }^{64}$ Rather, the Court notes that "[t]he Supreme

60. Frederick Mark Gedicks, A Two-Track Theory of the Establishment Clause, 43 B.C. L. REv. 1071, 1108 (2002), available at http://www.bc.edu/bc_org/avp/law/lwsch/journals/bclawr/43_5/03_ TXT.htm.

61. Jesse Merriam, Salazar v. Buono: Can Government Give One Religion's Symbol Prominence in a Public Park?, Pew Research Center Publications, Sept. 24, 2009, available at http://pewresearch .org/pubs/1353/salazar-buono-establishment-clause-religious-display.

62. See generally Mercier v. Fraternal Order of the Eagles, 395 F.3d 693 (7th Cir. 2005) and Buono v. Kempthorne, 527 F.3d 758 (9th Cir. 2008).

63. Mercier, 395 F.3d at 700 (citing Freedom from Religion Foundation, 203 F.3d at 491).

64. Buono, 502 F.3d at 759. 
Court's Establishment Clause jurisprudence recognizes the need to conduct a fact-specific inquiry in this area." ${ }^{\circ 5}$

\section{A. The Seventh Circuit Approach}

Two relatively recent decisions issued by the Seventh Circuit that demonstrate its approach to analyzing the constitutionality of land transfers are Freedom from Religion Foundation, Inc. v. City of Marshfield and Mercier v. Fraternal Order of Eagles.

The first of these two cases, Marshfield, was decided by the court in 1999. The case centered on a fifteen-foot-tall, white marble statue of Jesus Christ that was given as a gift from the Knights of Columbus to the city of Marshfield, Wisconsin in $1959 .{ }^{66}$ At the base of the statue was the inscription, in twelve-inch block letters, "Christ Guide Us On Our Way." ${ }^{67}$ After accepting the gift, the city of Marshfield placed the statue in an undeveloped, city-owned property known as Wildwood Park. ${ }^{68}$ Thirty-nine years later, in 1998, a local businessman and member of the Freedom from Religion Foundation objected to the presence of the statue on public property and requested that the city move the statue to private property ${ }^{69}$ The city refused this request, and eventually the plaintiffs filed a lawsuit in federal court seeking injunctive relief. $^{70}$ After the lawsuit was filed, the city sold a small section of the park to a private group of Marshfield citizens in order to circumvent any potential constitutional violations. ${ }^{71}$

After the district court granted summary judgment to defendants, the Seventh Circuit affirmed on the issue of whether the land sale was an effective remedy for the Establishment Clause violation. ${ }^{72}$ Despite the plaintiff's arguments that the transaction was merely a "'sweetheart deal'... concocted to circumvent the government action requirement of the Establishment Clause" and therefore constituted an endorsement of religion by the city, the court found the transaction to be valid, citing the facts that the fund had

65. Id

66. Freedom from Religion Foundation, 203 F.3d at 489.

67. Id.

68. $I d$.

69. Id.

70. Id.

71. The city sold 0.15 acres of land surrounding the statue to a group of Marshfield citizens known as the Henry Praschak Memorial Fund, Inc. for a price of $\$ 21,560$. The bid process met all Wisconsin statutory requirements for the sale of public land. See id. at 489-90.

72. Freedom from Religion Foundation, 203 F.3d at 493. 
performed the necessary formalities to effect a transfer of property, paid a fair price and assumed the traditional duties of ownership. ${ }^{73}$ Thus, because there were no extraordinary circumstances that justified disregarding the sale for the purposes of the city endorsing religion, the court concluded that the city did not engage in government action endorsing religion by selling the property, and thus the transfer was valid. ${ }^{74}$

The Seventh Circuit reached a similar result in the 2005 case of Mercier v. Fraternal Order of Eagles. ${ }^{75}$ At issue in this case was the location of a monument bearing an inscription of the Ten Commandments in a public park in La Crosse, Wisconsin. ${ }^{76}$ The statue was erected in 1965 by the Fraternal Order of Eagles, which was given permission by the city to install the monument. ${ }^{77}$ In 2002, after threats of lawsuits over the monument, the city council of La Crosse agreed to sell the monument to the Eagles along with a twenty-foot by twenty-two-foot parcel of land under and surrounding the monument. ${ }^{78}$ Again, the Seventh Circuit found that this transaction lacked any "unusual circumstances," and held that the transaction was a sufficient means of ending the government endorsement of religion. ${ }^{79}$ In its majority opinion, the court, citing the Marshfield opinion, provided examples of "the typical sort of improprieties that might cause us to disregard a transaction." ${ }^{" 80}$ Unusual circumstances, according to the court, "would include a sale that did not comply with applicable state law governing the sale of land by a municipality, a sale to a straw purchaser that left the City with continuing power to exercise the duties of ownership, or a sale well below fair market value resulting in a gift to a religious organization." ${ }^{81}$ Absent these or any other strange circumstances, the court held the transfer of the land to be an effective method for remedying an Establishment Clause violation.

These cases demonstrate the Seventh Circuit's rather lenient view of land transfers as an Establishment Clause violation remedy. The Seventh Circuit presumes that such transfers are valid, absent unusual circumstances that indicate a continuing government endorsement of religion. Based on the Marshfield and Mercier opinions, it appears as though a particular

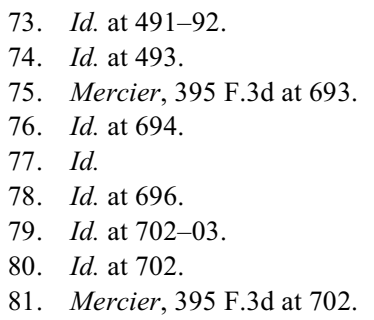


circumstance would have to be extremely unusual for the Seventh Circuit to consider it sufficient to terminate an otherwise valid transaction. For example, the court viewed the fact that the cities in both cases did not solicit alternative bids for the lands at issue as inconsequential to the transaction's validity. ${ }^{82}$ Based on these rulings, it is apparent that the Seventh Circuit's approach to these types of transactions is to generally uphold a transfer of land to a private entity unless some sort of obvious, egregious misconduct occurs. As this comment will demonstrate in the next section, the Ninth Circuit's approach has given substantially more scrutiny to these types of transactions.

\section{B. The Ninth Circuit Approach}

An analysis of the Ninth Circuit's approach to Establishment Clause cases involving a government sale of land requires an examination of the cases leading up to Salazar v. Buono. The controversy at the center of Salazar began in 2001, when Frank Buono, a former Assistant Superintendent of the Mojave National Preserve, brought an action challenging the constitutionality of the National Park Service's (NPS) maintenance of the cross atop Sunrise Rock. ${ }^{83}$ The district court, applying the Lemon test, ruled that the presence of the cross on federal land conveys a message of endorsement of religion, and granted summary judgment to Buono and his co-plaintiffs. ${ }^{84}$

Prior to this decision, however, Congress designated the cross a national memorial, and allocated federal funding to the NPS for the purpose of installing a memorial plaque at the site ${ }^{85}$ Following the district court's ruling that the statue be removed, Congress passed another law that banned the use of federal dollars to remove the cross, in an attempt to ensure that the court's order was not carried out. ${ }^{86}$ The NPS appealed the district court's ruling, and while the appeal was still pending, Congress passed another law requiring the secretary of the interior to transfer ownership of Sunrise Rock and a surrounding acre to the Veterans of Foreign Wars (VFW) ${ }^{87}$

In 2004, prior to this transfer of the property, the Ninth Circuit affirmed the district court's ruling, holding that the location of the statue in the Preserve was unconstitutional despite the fact that the cross was erected and maintained

82. Id. at 703 .

83. Buono v. Norton, 212 F. Supp. 2d 1202, 1207 (C.D. Cal. 2002).

84. Id. at 1214-17.

85. Merriam, supra note 61.

86. Id.

87. $I d$. 
by private individuals, and was intended to serve as war memorial. ${ }^{88}$ Furthermore, the Court held that the relatively small size of the cross and its remote location are of no consequence to its decision. Despite the short height of the cross, the Court reasoned that this makes it no less likely to project a message of government endorsement to a reasonable observer. ${ }^{89}$ Furthermore, the Court held that the cross's remote location was insignificant. The lack of a government-owned building in the vicinity of the cross is irrelevant; the only significant matter is that the cross sits on public park land, which "embod[ies] the notion of government ownership as much as urban parkland, and the remote location of Sunrise Rock does nothing to detract from that notion."

Despite the Ninth Circuit affirming that the statue was unconstitutional, the NPS did not remove the statue, but rather took steps to transfer the land to the VFW. ${ }^{91}$ This action led Buono to file another lawsuit in district court, this time seeking an injunction on the transfer of the land from the NPS to the VFW. ${ }^{92}$ In that case, the district court again declared the statue unconstitutional, and enjoined the NPS from transferring the land. ${ }^{93}$ In declaring the transfer invalid, the court determined that unusual circumstances surrounded the transfer. ${ }^{94}$ Specifically, the court cited to the fact that the NPS retained a reversionary interest in the property, that the decision to transfer the land did not occur through the normal administrative process, and the history of the government's efforts to preserve and maintain the Sunrise Rock cross as unusual circumstances. ${ }^{95}$

Again, the NPS appealed this ruling to the Ninth Circuit, with the same result. ${ }^{96}$ In upholding the district court's ruling, the Ninth Circuit considered the same circumstances surrounding the transfer, and concluded that the government engaged in "herculean efforts" to preserve the cross atop Sunrise Rock. ${ }^{97}$ Finally, in 2008, the Ninth Circuit issued an amended opinion, adding a footnote which explained that while the court agreed with the Seventh Circuit's approach of looking at these cases on a transaction by transaction basis, it declined to adopt a presumption of the effectiveness of a land sale to

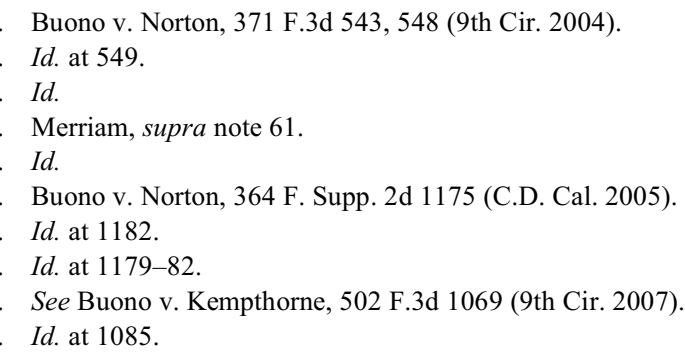


end a constitutional violation. ${ }^{98}$ Thus, the Ninth Circuit, while adopting the Seventh Circuit's unusual circumstances test, views such transactions with far more scrutiny than the Seventh Circuit.

\section{The Supreme Court's Ruling in Salazar v. Buono}

On April 28, 2010, the United States Supreme Court, in a 5-4 decision, reversed the ruling of the Ninth Circuit and remanded the case. Justice Kennedy, writing for the plurality, held that the District Court in Buono v. Norton incorrectly enjoined the land transfer on the basis of suspicion of an illicit governmental purpose, rather than on perception, which was the sole basis for the 2002 injunction. ${ }^{99}$ Justice Kennedy presumed that the 2002 injunction was valid, but suggested that he did not necessarily agree with the ruling, stating that " $[t]$ he goal of avoiding governmental endorsement does not require eradication of all religious symbols in the public realm."100 Justice Alito, concurring in part and in the judgment, wrote that the actions taken by Congress were appropriate, noting that the transfer would "eliminate any perception of religious sponsorship stemming from the location of the cross on federally owned land, while at the same time avoiding the disturbing symbolism associated with the destruction of the historic monument." ${ }^{101}$ As a result, Justice Alito did not believe that it was necessary to remand the case to the lower court. ${ }^{102}$

Justice Stevens, joined by Justices Ginsburg and Sotomayor, dissented, writing that "[a] Latin cross necessarily symbolizes one of the most important tenets upon which believers in a benevolent Creator, as well as non-believers, are known to differ." 103 While Justice Stevens agreed that "the Nation should memorialize the service of those who fought and died in World War I," he held that "it cannot lawfully do so by continued endorsement of a starkly sectarian message." 104 In Justice Stevens' view, the transfer would not end government endorsement of the cross because "after the transfer it would continue to appear to any reasonable observer that the Government has endorsed the cross," since the government has designated it as a national

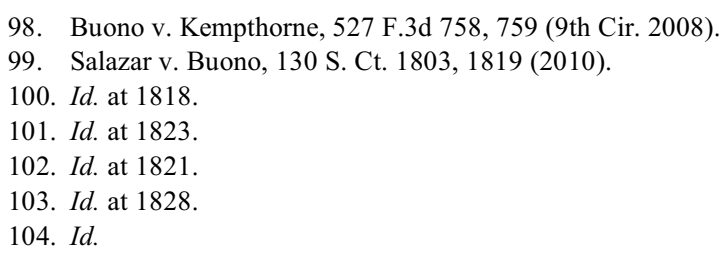


memorial, and because the purpose of the transfer is to preserve the display of the cross. ${ }^{105}$ Given the transfer statute's fundamental inadequacy as a remedy for the Establishment Clause violation, Justice Stevens concluded that there is no need to remand to the district court. ${ }^{106}$

\section{ANALysis}

In deciding Salazar v. Buono and determining the constitutionality of such transactions, the Court was faced with weighing two major competing interests: upholding and recognizing the continuing importance of the Establishment Clause, versus the potential implications that the ruling could have on the ability to transfer and control property. This comment argues that, while the Seventh Circuit and Ninth Circuit rationales both have merit, the Court should have affirmed the Ninth Circuit's ruling in this particular case.

In his dissenting opinion in the Ninth Circuit's most recent Buono decision, Justice O'Scannlain expressed a great deal of concern over the majority's ruling. ${ }^{107}$ One of Justice O'Scannlain's concerns is that the Ninth Circuit inappropriately expanded the scope of the "unusual circumstances" test by holding that the government has maintained or will maintain or support the Sunrise Rock cross after the land transfer despite the lack of any evidence indicating that this is the case. ${ }^{108}$ Furthermore, Justice O'Scannlain criticizes the majority's opinion on the basis that it creates a possibility in which a private citizen's rights may be infringed upon simply because of the fact that his land was publicly owned in the past. ${ }^{109}$ Essentially, the Justice's argument in his dissent is that the majority's ruling could harm potential recipients of land in these types of transactions, because they may be forced to suffer the consequences of the government's constitutional violation long after the government's endorsement of religion has ended.

Based on the facts of the Buono case, it is apparent that the Ninth Circuit did not inappropriately expand upon the unusual circumstances test. The transaction at issue in Buono was suspicious in a number of respects. Aside from the reasons cited by the Ninth Circuit, such as the reversionary interest in the land held by the government, and the bypassing of required

105. Salazar, 130 S. Ct. at $1832-33$.

106. Id. at 1841 .

107. Buono v. Kempthorne, 527 F.3d 758, 760 (9th Cir. 2008).

108. Id. at 763 .

109. Id. at 764 . 
administrative procedures,${ }^{110}$ the timing of the transaction should have raised questions. In 1999, prior to the initial complaints about the cross, a Utah resident and retired NPS employee inquired with the NPS about the possibility of erecting a stupa (a dome-shaped Buddhist shrine) on a rock outcrop located near the cross. ${ }^{111}$ The NPS quickly informed the individual that it was prohibited by agency regulations from installing any type of religious symbol on the publicly-owned land, and that it would remove the cross. ${ }^{112}$ Shortly thereafter, Congress passed a law prohibiting the use of government funds to remove the cross. ${ }^{113}$ Congress also passed a law that designated the cross as a national memorial to veterans, ${ }^{114}$ despite the immensely diverse ethnic and religious population in the United States, and the fact that thirty-two percent of the current U.S. military does not identify themselves as belonging to a Christian faith. ${ }^{15}$

Furthermore, the designation of the cross as a national memorial made it one of only forty-nine such memorials in the entire United States. ${ }^{116}$ The designation of this small, little-known cross, located in a very remote area and seen by few, as a national memorial when such a designation is relatively rare should have further raised suspicions about the federal government's motives. The combination of all these factors should have been more than enough to, at a minimum, raise suspicion that the government is transferring land for the sole purpose of circumventing the Establishment Clause. While

" $[\mathrm{u}]$ nusual circumstances that will invalidate a sale include (1) 'a sale to a straw purchaser' leaving the public entity 'with continuing power to exercise the duties of ownership,' (2) 'a sale that does not comply with' applicable law governing the sale of land by a public entity, or (3) a sale well below fair market value resulting in a gift to a religious organization," courts have held that "[a]ll of these unusual circumstances need not exist to invalidate a sale and a court may also consider the existence of other unusual circumstances in this analysis." 117

110. Buono v. Norton, 364 F. Supp. 2d 1175, 1181 (C.D. Cal. 2005).

111. Buono v. Kempthorne, 527 F.3d 758, 769 (9th Cir. 2008).

112. Id.

113. Id. See Pub. L. No. 106-554 § 133, 114 Stat. 2763A-230 (2000):

None of the funds in this or any other Act may be used by the Secretary of the Interior to remove the five-foot-tall white cross located within the boundary of the Mojave National Preserve in southern California first erected in 1934 by the Veterans of Foreign Wars along Cima Road approximately 11 miles south of Interstate 15. § 113 (emphasis added).

114. Merriam, supra note 61.

115. Drazin, supra note 7 (eleven percent of current active members of the military say they belong to a non-Christian faith, while twenty-one percent are atheists or report no religion).

116. $I d$.

117. Buono v. Norton, 364 F. Supp. 2d 1175, 1178-79 (C.D. Cal. 2005), citing Mercier, 395 F.3d 
The Seventh Circuit's unusual circumstances test appears to be an appropriate test in analyzing the validity of these types of transactions. However, the test is completely ineffective unless Courts apply a level of scrutiny to the extent that the Ninth Circuit has. The circumstances in the Buono line of cases were clearly unusual enough to warrant increased scrutiny. Thus, the Ninth Circuit has not inappropriately expanded the test; they have simply carried it out more effectively than the Seventh Circuit and the adherents to the Seventh Circuit approach.

Critics of the Ninth Circuit's ruling in Buono v. Kempthorne also point to the potentially harmful effect that such a ruling could have on the beneficiaries of land in such cases. ${ }^{118}$ This argument, while valid, tends to exaggerate the potential harm to private citizen's rights, while de-emphasizing the importance of the separation between church and state. In cases like these, the private citizen often has limited rights as a result of the transaction anyway. "The private beneficiary of the land transfer performs functions normally under the umbrella of the state." ${ }^{119}$ In the Buono line of cases, for example, the terms of the conveyance include a condition that the land, as well as the replica cross and commemorative plaque purchased with government funds, be maintained as a memorial by the recipient, the Veterans of Foreign Wars. ${ }^{120}$ In cases like these, although the transaction removed the government from legal ownership of the land containing the religious symbol, "government action persists in substance, as does the expression of a patently religious symbol on what is perceived to be public land." 121 Thus, rights of the private parties involved in these types of cases, which generally only serve as a "mask" for government action, are actually not encroached upon. Nonetheless, this is an issue that should be considered by the Court when analyzing government land transfers to private entities. If a particular transaction in which a private entity purchases land from the federal government creates a significantly onerous burden on the private entity due to the government's First Amendment violation, such a result should be factored into whether the sale is an effective remedy.

at 702 .

118. See generally David Brewer, Comment, A Cross in the Road: Salazar v. Buono and the Circuit Divide on the Establishment Clause Remedial Question, 58 CATH. U. L. Rev. 813, 844 (2009).

119. David C. Peet, Comment, Deed of Mistrust? The Use of Land Transfers to Evade the Establishment Clause, 59 AM. U. L. Rev. 129, 147 (2009).

120. Id. at 147.

121. Id. at 151. 
Some commentators also argue that the Seventh Circuit's approach to cases involving the transfer of land to a private entity is preferable to the Ninth Circuit's because it affords local governments flexibility to remedy Establishment Clause violations with creative solutions. ${ }^{122}$ Municipalities today are faced with increasing complexities of governance as America continues to become more religiously and culturally diverse. ${ }^{123}$ The Seventh Circuit, by presuming that such transactions are an effective remedy to Establishment Clause violations, allows governments to come up with solutions other than the "take-it-or-leave-it approach to the religious display." "24 This all or nothing approach is often undesirable, as questions of religious displays can generate a tremendous amount of emotion, and thus the removal or keeping of a symbol may create a volatile situation. ${ }^{125}$

There is a problem with this argument, however. Increasing the government's flexibility in crafting solutions to Establishment Clause violations would inevitably lead to a potential increase in the government's ability to act favorably toward a particular religion. The government should only be permitted to engage in land transfers to private citizens in the most obviously constitutional situations. Following the Seventh Circuit approach would allow governments to engage in different types of transactions that would increase the potential for abuse. Furthermore, allowing governments flexibility in these types of transactions could have additional negative policy implications. For one, "[a]ny entity desirous of erecting a permanent religious symbol on public land would have what amounts to a court-established right to a piece of the commons." ${ }^{126}$ This could open the door for unpopular religious groups to freely erect symbols on public land. Essentially, "carving out public lands into private parcels to appease particular religious groups seems more likely to potentially invite religious tension rather than alleviate it." $" 127$

Based on the aforementioned factors, the Supreme Court should have affirmed the Ninth Circuit's decision in Buono v. Kempthorne. The circumstances surrounding the transfer of land from a government entity to a private one need to be thoroughly analyzed, and the particular facts of each and every situation need to be taken into account. In addition to the typical

122. Brewer, supra note 118 , at 844 .

123. Id. at 846 .

124. Id. at 844 .

125. Id. at 846 .

126. Peet, supra note 120 , at 154.

127. Id. at 155 . 
factors examined by the Seventh Circuit in determining whether "unusual circumstances" surrounded a transaction, courts should also take into account factors such as how long the religious symbol in question has been at a particular site, the community attitudes about the symbol, and other factors that may affect a government's tendency to engage in "sham" transactions. These types of factors further help to illuminate the government's rationale behind transferring land to a private entity, and thus help to determine the legitimacy of such transactions.

For example, if a particular religious monument has been an important part of a community for several decades, as the cross at issue in Salazar $v$. Buono was, and is held by the community members to be an important aspect of the community's identity, a sale of the land containing the monument by the local government to a private entity should be viewed with additional scrutiny. Such a transaction should be subject to additional scrutiny because it would likely be in the local government's best interest to maintain the monument, due to its popularity with citizens. In such a case, therefore, the government's tendency to engage in a "sham" transaction in order to circumvent the Establishment Clause would be at its highest. If it is not in the economic interest of the governmental entity, but merely a way to overcome an Establishment Clause violation, such a transfer should be found to be invalid.

Additionally, the Court should assess the level of actual harm that prohibiting a transfer of land from the government to a private entity would truly have on the private actor. For example, the actual financial burden that the prohibition would create for the private entity, as well as the level of inconvenience of having to bear the burden of the ramifications for the government's violations, should be weighed in these types of cases. It will be up to the reviewing court to examine these transactions on a case-by-case basis and determine whether the interests of the private entity are affected in a significant enough way to justify the transfer of the land from a governmental entity.

\section{CONCLUSION}

The Establishment Clause retains an important role in our society today. With the ever-increasing religious diversity of the United States comes the continued importance of a strong prohibition against the establishment of law pertaining to religion or the endorsement by the government of any particular religion. While there are many significant interests to be considered in determining the validity of transactions involving the sale of public land 
containing a religious symbol to a private entity, the separation of church and state should remain the strongest.

Justice Kennedy's plurality opinion in Salazar v. Buono does not absolutely foreclose the possibility of land transfers as an effective way to overcome an Establishment Clause violation. The opinion correctly recognizes that a complete eradication of religious symbols in public places is neither practical nor required. As the Supreme Court demonstrated in Lynch $v$. Donnelly, there are countless examples in everyday life of the intersection of government and religion. ${ }^{128}$ Governmental entities have proclaimed days with religious origins, such as Thanksgiving and Christmas, to be national holidays, in which federal employees are released from their duties and are paid with federal funds. ${ }^{129}$ The Pledge of Allegiance, the National Anthem, and even the currency of the United States contain references to God. ${ }^{130}$ National galleries, maintained with government support, contain many masterpieces which contain religious messages. ${ }^{131}$ In other words, a total denial by the Courts that there is interaction between the government and religion is neither realistic nor desirable.

However, even given these principles, the Supreme Court should have affirmed the Ninth Circuit's ruling in Buono v. Kempthorne and upheld the ruling that the government's action was unconstitutional. While the sale of land can be an effective remedy for Establishment Clause violations, these types of transactions must be viewed with more scrutiny than the Seventh Circuit, and the plurality in Salazar, has viewed them with up to this point. These types of transfers should only be allowed in situations where any "unusual circumstances" surrounding the sale are absent, and where the potential detriment to the private entity resulting from the denial of the transfer substantially outweighs any First Amendment concerns. The facts of Salazar v. Buono clearly suggest that the land transfer failed to adequately remedy the Establishment Clause violation, because of the presence of unusual circumstances and minimal detriment to the private entity receiving the land. The wall between church and state should remain as strong as possible, but as a practical matter cannot be completely impenetrable. However, Courts should not recognize this principle at the expense of the Establishment Clause, as the plurality did in Salazar v. Buono.

128. Lynch, 465 U.S. at 676.

129. Id.

130. $I d$.

131. Id. 